\title{
KANTAVATKO TULES-KUNTOUTUKSESSA ASETETUT TAVOITTEET?
}

\section{Johdanto}

Tuki- ja liikuntaelimistön sairaudet (tules) vaikuttavat merkittävästi väestön työkykyisyyteen. Vuonna 2016 ne aiheuttivat eniten sairauspoissaoloja, yleisimpinä syinä selkäsairaus, selkäsärky, nikamavälilevyjen sairaus tai hartiaseudun pehmytkudossairaus. (Kela 2017a.) Kelan kuntoutukseen hakeutumisen syistä tuki- ja liikuntaelimistön sairaudet ovat toiseksi yleisin syyryhmä, ja yhteensä 23500 henkilöä sai Kelan järjestämää kuntoutusta tuki- ja liikuntaelimistön vaivoihin vuonna 2016 (Kela 2017b).

Tules-kuntoutuksen päämääränä on kuntoutujan kokonaisvaltaisen hyvinvoinnin ja arkipäivän toiminnoista suoriutumisen sekä työssä selviytymisen vahvistuminen (Häkkinen ym. 2014). Kuntoutus sisältää tuki- ja liikuntaelimistön ongelmiin kohdistuvan harjoittelun lisäksi kuntoutujan alentunutta fyysistä suorituskykyä lisääviä toimenpiteitä, joilla vähennetään kuormittumista vapaa-aikana ja työelämässä (Hutting ym. 2017, Häkkinen ym. 2014). Huttingin ja kumppaneiden (2017) tutkimus osoitti, että työ tuottaa tules-kuntoutujille toimeentulon ohella merkitystä ja mielihyvää elämään. Vastaavasti työelämästä poissa ololla voi olla kuntoutujan hyvinvointiin merkittäviä vaikutuksia. Toisaalta työ voi olla myös este kuntoutumiselle, jos se vaikeuttaa tuki- ja liikuntaelimistön ongelmia tai työympäristö ei ole kuntoutujalle sopiva. Näiden tekijöiden vuoksi työikäisillä kuntoutujilla työn ja kuntoutuksen pitäisi vahvasti linkittyä toisiinsa. (Hutting ym. 2017.)

Kuntoutus on lähtökohtaisesti asiakaslähtöistä toimintaa, jossa keskeistä on jaettu päätöksenteko ja toimijuus sekä asiakkaan toiveiden kuunteleminen (Reunanen 2017, Rose ym. 2017, Saito ym. 2019). Kuntoutumista ohjaavat kuntoutujan oma toiminta ja hänen itse määrittelemänsä tavoitteet (Kuntoutuksen uudistamiskomitea 2017, Autti-Rämö \&t Salminen 2016), joiden tulisi olla kuntoutujalle merkityksellisiä ja realistisesti saavutettavissa olevia (Bovend'Eerdt ym. 2009). Viimeaikaisten tutkimusten perusteella asiakkaan toiveiden muuntuminen kuntoutuksen tavoitteiksi ei kuitenkaan aina toteudu (Saito ym. 2019, Barnard ym. 2010).

Ammattilaisjohtoisuuden on havaittu näkyvän niin, että kuntoutujien omista toiveista ja heidän nimeämistään arkipäivän ongelmista muotoutuu kuntoutustiimissä tavoitteita, joita kuntoutujat eivät enää itse tunnista omikseen (Saito ym. 2019, Barnard ym. 2010). Tutkimusten mukaan kuntoutujan osallistamisessa tavoitteen asettamiseen on suurta vaihtelua ja ammattilaisten keinot osallistaa kuntoutujia mukaan tavoitteiden asetteluun tarvitsevat vahvistusta. Kuntoutujan toiveiden kuunteleminen ja niistä yhdessä keskustelemalla tavoitteiden 
nimeäminen luovat tunnetta yhteisestä ymmärryksestä, mikä auttaa kuntoutujaa sitoutumaan tavoitteisiin. (Rose ym. 2019, Saito ym. 2019.) Ammattilaisen tulisikin, kuntoutuksen teknisen asiantuntijuuden lisäksi, olla vähintäänkin tietoinen kuntoutusprosessia koskevista omista ajatuksistaan ja tunteistaan sekä työskentelytavoistaan (Kayes ym. 2015, 263).

Kuntoutumisen tavoitteita lähestytään entistä enemmän yksilöllisten merkitysten ja kuntoutujan elämäntavoitteisiin nivoutumisen kautta. Dekker (2020) on esitellyt tavoitteen asettamisen mallin, jossa ensin tunnistetaan kuntoutujan kanssa keskustellen hänen elämäänsä liittyvä laajempi tavoite. Tämän jälkeen kuntoutuksen spesifit tavoitteet määritellään niin, että ne tukevat elämäntavoitteiden saavuttamista. Vastaavasti McPherson ym. (2015) kuvaavat MEANING-periaatteella $(\mathrm{M}$ = meaning, $\mathrm{E}=$ engage, $\mathrm{A}=$ anchor, $\mathrm{N}=$ negotiate, $\mathrm{I}=$ intention-implementation gap, $\mathrm{N}=$ new goals, $\mathrm{G}=$ goals as behaviour change) tavoitteiden merkityksellisyyttä. Lisäksi he nostavat tärkeiksi elementeiksi kuntoutujan osallistamisen, tavoitteen linkittämisen pienempiin kokonaisuuksiin, etenemisestä keskustelemisen ja konkreettisten etenemissuunnitelmien laatimisen, tavoitteiden saavuttamisen jälkeen uusien tavoitteiden laatimisen sekä tavoitteiden ymmärtämisen käyttäytymisen muuttamisen keinona. (McPherson ym. 2015, 112-114.)

Myös tavoitteiden saavuttamista edistävä toiminta nähdään monitahoisena prosessina, johon ei suoraan päde kausaalisen, syy-seuraussuhteen lainalaisuudet. Esimerkiksi Scobbie ja kumppanit (2011) kehittivät lineaarisesta tavoite - toimenpide - tulos-ketjusta kehämäisen tavoitteiden asettamisen ja toiminnan suunnittelun käytännön viitekehyksen (Goal setting and action planning, G-AP framework). G-AP-viitekehyksessä kuntoutuja ja ammattilaiset yhdessä laativat konkreettiset etenemissuunnitelmat, joissa on kuvattu mitä, milloin, missä ja kuinka usein on tehtävä, jotta tavoite voidaan saavuttaa. Samalla arvioidaan kuntoutujan kokemusta siitä, miten pystyvä hän on toteuttamaan suunnitelmia. Tavoitteen saavuttamista sekä sitä edistäviä ja estäviä tekijöitä analysoidaan prosessin kuluessa ja ymmärryksen lisääntyessä. Tarpeen mukaan muutetaan tavoitteita ja suunnataan toimintaa uudella tavalla.

Kelan järjestämien tules-kuntoutuskurssien toteuttamista ohjataan palvelukuvauksilla, jotka antavat kuntoutuksen toteuttamiselle teoreettiset ja käytännölliset kehykset, kuten sisällön, rakenteen ja laatuvaatimukset (Kela 2016a, b, c). Palvelukuvaus ohjaa hyödyntämään tules-kuntoutuksessa ICF-luokitukseen (WHO:n toimintakyvyn, toimintarajoitteiden ja terveyden kansainväliseen luokitukseen) perustuvaa lähestymistapaa. Palvelukuvausten asettamissa rajoissa palveluntuottajilla on mahdollisuus suunnitella ja toteuttaa kuntoutuskurssit omien resurssiensa, ammattiosaamisensa ja tarpeidensa mukaan. Yhdeksän kuukauden kestoiset tules-kuntoutuskurssit toteutuvat joko laitosmuotoisina tai avomuotoisina. Laitosmuotoinen tules-kuntoutus toteutetaan kolmena viiden päivän kuntoutusjaksona. Avomuotoinen tules-kuntoutus on vuonna 2016 aloitettu uudenlainen palvelumuoto, joka sisältää viisi ryhmämuotoista avokuntoutuspäivää ja kymmenen ryhmämuotoista, puolen päivän mittaista käyntikertaa kahden tai kolmen viikon välein.

Palvelukuvauksessa on tules-kurssien yleiseksi tavoitteeksi määritelty kuntoutujan fyysisen, psyykkisen, kognitiivisen ja sosiaalisen työ- tai opiskelu- tai toimintakyvyn tukeminen. Tavoitteena on myös lisätä kuntoutujan aktiivisuutta ja osallisuutta hänen omissa arjen ympäristöissään. (Kela 2016a, b, c.) Kunkin kuntoutujaryhmän tavoitteet määritellään ryhmäkeskusteluissa, ja ne täydentävät kyseessä olevan tules-kurssin kuntoutusohjelmaa, jonka palveluntuottajat ovat laatineet ennalta. Kuntoutujan yksilölliset tavoitteet kurssille laaditaan yhteistyössä ammattilaisten ja kuntoutujan kesken GAS-menetelmällä (Goal Attainment Scaling). (Kela 2016b, c.)

Kelan kuntoutuksessa käytettävä GASmenetelmä mahdollistaa kunkin kuntoutujan oman tavoitteen saavuttamisen arvioinnin ja myös tietyn kuntoutujajoukon keskimääräisen tavoitteen saavuttamisen arvioinnin. GAS-menetelmän käytön on todettu lisäävän 
kommunikaatiota ja monialaista yhteistyötä, kuntoutujan motivaatiota ja vastuun ottamista kuntoutumisesta sekä ohjaavan kuntoutujan tarpeita tukevien toimien suunnittelua. (Stevens ym. 2013, Laukkala ym. 2015, Karhula ym. 2016.) Kritiikkinä GAS-menetelmää kohtaan on esitetty sen työläys: tavoitteiden tunnistaminen ja asteikon laatiminen vievät aikaa. Oman haasteensa asettaa tavoitteen saavuttamiseen liittyvien, kuntoutuja- ja tilannekohtaisten tekijöiden moninaisuus. Kuitenkin kokonaisuudessaan GAS-menetelmän on katsottu olevan käyttökelpoinen tavoitteiden asettamisen menetelmä. (Siegert \&t Levack 2015.)

Kuten koko Kelan MUUTOS-hankkeen, niin myös tules-osatutkimuksen tarkoituksena oli tarkastella vuoden 2016 palvelukuvauksen vaikutuksia tules-kuntoutuskurssien toteutukseen ja toimivuuteen sekä kuntoutujan saamaan palveluun (Karhula ym. 2019, 14, Seppänen-Järvelä 2017).

Tules-osatutkimus oli luonteeltaan imple- mentaatiotutkimus, jossa tieto tuotetaan prosessimaisesti. Tules-kuntoutuskursseja ohjaavat vuoden 2016 palvelukuvaukset, joiden toteutuksesta saatua tutkimustietoa hyödynnettiin seuraavassa palvelukuvauksessa. Tiedon tuottamisessa huomioitiin kuntoutujien ja ammattilaisten näkemykset sekä palveluun järjestämiseen ja tuottamiseen vaikuttavat poliittiset, taloudelliset ja organisatoriset kontekstit. (Seppänen-Järvelä 2017, Wensing 2015.)

Tässä artikkelissa syvennämme ja tarkennamme tutkimuksen raportissa kuvattuja, tules-kuntoutuskurssien tavoitteisiin liittyviä teemoja. Erityisenä tarkastelun kohteenamme on tavoitteiden näyttäytyminen kuntoutusprosessissa kuntoutujien ja palveluntuottajien näkemysten sekä kuntoutujan omat tavoitteet -lomakkeiden valossa. Vastaamme seuraaviin kysymyksiin: 1) mitä tules-kuntoutuksen tavoitteet olivat, 2) miten tavoitteet ohjasivat kuntoutusta ja kuntoutumista ja 3) miten hyvin tavoitteet saavutettiin?

Taulukko 1. Tutkimuksen eri aineistoista saatu tieto tules-kuntoutuksen tavoitteista.

\begin{tabular}{|c|c|c|c|c|}
\hline $\begin{array}{l}\text { Omat tavoitteet } \\
\text { lomakkeet } \\
(n=75), \text { joissa } \\
\text { |6| tavoitetta }\end{array}$ & $\begin{array}{l}\text { Kuntoutujien } \\
\text { ryhmähaastat- } \\
\text { telut }(n=10)\end{array}$ & $\begin{array}{l}\text { Palveluntuottajien } \\
\text { ryhmähaastattelut } \\
(n=10)\end{array}$ & $\begin{array}{l}\text { Kuntoutujien } \\
\text { kyselyt } \\
(n=I 839)\end{array}$ & $\begin{array}{l}\text { Palveluntuottajien } \\
\text { kyselyt }(n=26)\end{array}$ \\
\hline $\begin{array}{l}\text { Mitä tavoitteita } \\
\text { kuntoutujat } \\
\text { asettivat? }\end{array}$ & $\begin{array}{l}\text { Miten tavoite } \\
\text { ohjasi } \\
\text { kuntoutumista? }\end{array}$ & $\begin{array}{l}\text { Miten tavoitteen } \\
\text { asettaminen } \\
\text { toteutettiin? }\end{array}$ & $\begin{array}{l}\text { Miten tavoite } \\
\text { asetettiin? }\end{array}$ & $\begin{array}{l}\text { Miten tavoite } \\
\text { asetettiin? }\end{array}$ \\
\hline $\begin{array}{l}\text { Miten tavoitteet } \\
\text { olivat muotoiltu? }\end{array}$ & $\begin{array}{l}\text { Miten tavoitetta } \\
\text { arvioitiin } \\
\text { kuntoutuksen } \\
\text { aikana? }\end{array}$ & $\begin{array}{l}\text { Miten tavoite ohjasi } \\
\text { kuntoutusta? }\end{array}$ & $\begin{array}{l}\text { Miten tavoitteita } \\
\text { arvioitiin? }\end{array}$ & $\begin{array}{l}\text { Miten tavoitteita } \\
\text { arvioitiin? }\end{array}$ \\
\hline \multirow[t]{2}{*}{$\begin{array}{l}\text { Miten kuntoutujat } \\
\text { saavuttivat } \\
\text { tavoitteensa? }\end{array}$} & $\begin{array}{l}\text { Miten tavoitteita } \\
\text { tukevista kei- } \\
\text { noista puhuttiin } \\
\text { tai mietittiin } \\
\text { yhdessä ammat- } \\
\text { tilaisten kanssa? }\end{array}$ & $\begin{array}{l}\text { Miten GAS mene- } \\
\text { telmään tutustuttiin } \\
\text { kuntoutujien kans- } \\
\text { sa? } \\
\text { Miten tavoitteita } \\
\text { tukevista keinoista } \\
\text { puhuttiin tai mie- } \\
\text { tittiin yhdessä kun- } \\
\text { toutujien kanssa? }\end{array}$ & $\begin{array}{l}\text { Miten kuntou- } \\
\text { tujat arvioivat } \\
\text { saavuttaneensa } \\
\text { tavoitteet? }\end{array}$ & \\
\hline & & $\begin{array}{l}\text { Olivatko tavoitteet } \\
\text { mielekkäitä } \\
\text { kuntoutujan } \\
\text { näkökulmasta? }\end{array}$ & $\begin{array}{l}\text { Olivatko tavoit- } \\
\text { teet mielekkäitä } \\
\text { kuntoutumisen } \\
\text { näkökulmasta? }\end{array}$ & \\
\hline
\end{tabular}




\section{Menetelmät ja aineistot}

Tules-tutkimuksessa aineisto rakentui kuntoutujien ja palveluntuottajien kyselyistä ja heidän ryhmähaastatteluistaan sekä kuntoutujien GAS-tavoitelomakkeista (kuntoutujan omat tavoitteet -lomakkeista). Sormusen (2013) mukaan monimenetelmällisen tutkimuksen tarkoituksena on tuottaa käytännöllistä ja monipuolista tietoa yhdistäen laadullinen ja määrällinen metodologia. Kuntoutujan omien tavoitteiden ohjaama kuntoutus ja kuntoutuminen ovat kompleksisia ilmiöitä, eikä tutkimuskysymyksiin vastaaminen olisi onnistunut yksittäistä aineistonkeruumenetelmää käyttäen (vrt. Sormunen ym. 2013, Seppänen-Järvelä ym. 2019). Kuntoutuja tarvitsee ammattilaista tavoitetyöskentelyn eri vaiheissa. Kuitenkin ammattilaisen ja kuntoutujan työskentelyn intressit voivat erota toisistaan, joten monimenetelmällisen tutkimusotteen hyödyntäminen oli perusteltua (Seppänen-Järvelä ym. 2019).

Tutkimuksessa määrälliset ja laadulliset aineistot analysoitiin ensin omien metodiensa mukaisesti, minkä jälkeen analyysien tulokset yhdistettiin tutkimuskysymysten teemojen mukaisesti (Karhula ym. 2019, 16-17). Kaikki tutkimusaineistot (kyselyt, haastattelut ja omat tavoitteeni -lomakkeet) olivat keskenään samanarvoisia (ks. taulukko 1) ja niitä käytettiin analyysissä täydentämään toisiaan.

Monimenetelmällisessä tutkimuksessa aineistojen kerääminen ja analysointi vuorottelivat (kuvio 1). Näin aineistot rakentuivat toistensa päälle ja sisäkkäin muodostaen yhtenäisen kuvauksen ilmiöstä (vrt. Seppänen-Järvelä ym. 2019).

Kyselyssä kuntoutujat arvioivat kuntoutuksen sisältöjä ja toteutumista (ks. kysymykset tarkemmin Karhula ym. 2019, liite 2). Vastausprosentti perustui niihin henkilömääriin, jotka palveluntuottajat ilmoittivat rekrytoineensa vastaamaan kyselyyn. Kuntoutujien kyselyihin vastasi yhteensä 1839 kuntoutujaa, ja vastausprosentti oli 26. Palveluntuottajakohtaisissa vastausprosenteissa oli suurta variaatiota. Vastausprosenttia heikensi yhden palveluntuottajan, joka toteutti määrällisesti paljon tules-kuntoutusta, heikko vastausprosentti. (Ks. tarkemmin Karhula ym. 2019, liite 4.) Vastaajista laitosmuotoiseen kuntoutukseen oli osallistunut 1441 kuntoutujaa ja avomuotoiseen kuntoutukseen 398 kuntoutujaa. Taustatietoina kuntoutujilta kysyttiin ikä, sukupuoli, kuntoutusmuoto (laitosmuotoinen/avomuotoinen), kuntoutuskurssin kohdentuminen sekä palveluntuottaja. Tarkempia henkilö- tai diagnoositietoja ei kuntoutujilta kysytty. Vastaa-

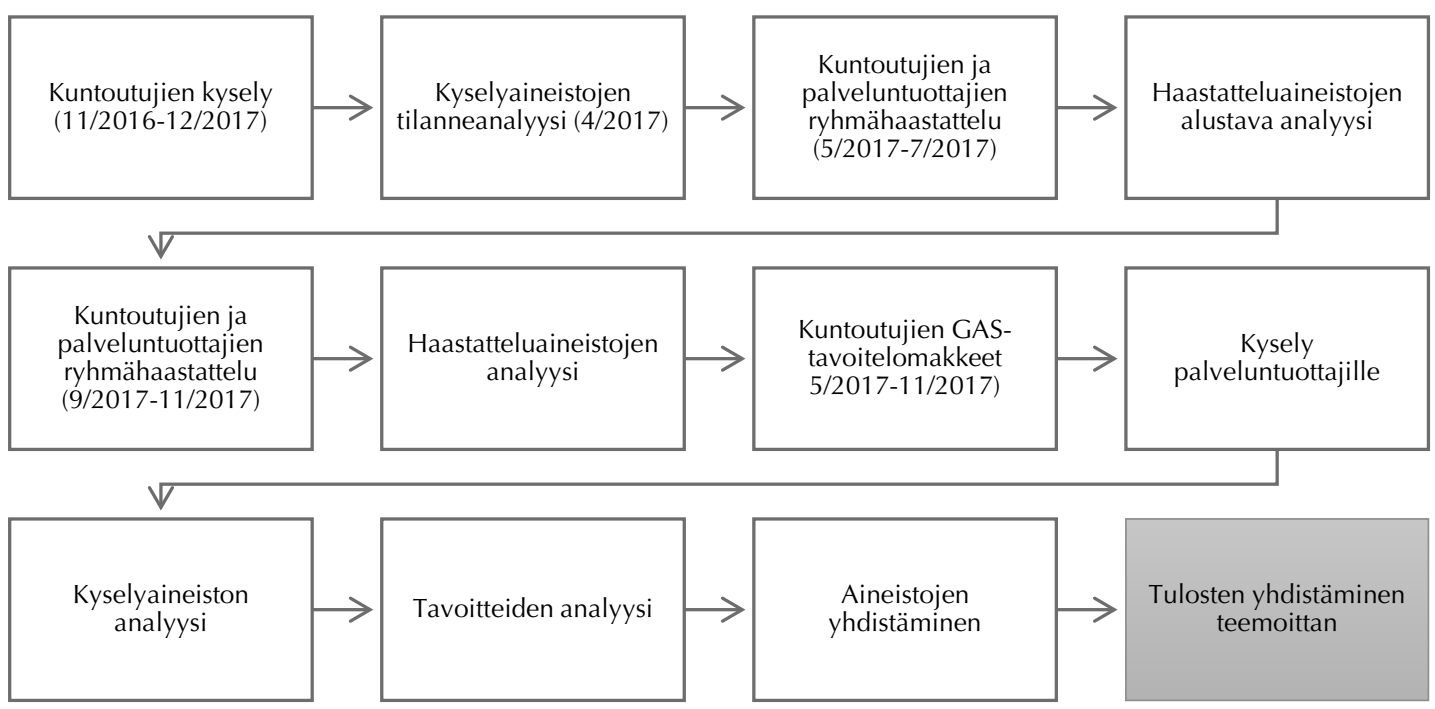

Kuvio 1. Aineistojen keruun ja analysoinnin eteneminen. 
jista 72 prosenttia oli naisia sekä laitos- että avomuotoiseen kuntoutukseen osallistuneiden aineistoissa. Iältään laitosmuotoiseen kuntoutukseen osallistujat olivat tilastollisesti merkitsevästi vanhempia kuin avomuotoiseen kuntoutukseen osallistujat; iän keskiarvo oli laitosmuotoisessa kuntoutuksessa 53 vuotta ja avomuotoisessa kuntoutuksessa 51 vuotta. Kuntoutujille annettiin kyselyn vastauslinkki kuntoutuksen loppuvaiheessa. Tules-kuntoutusta toteuttavia palveluntuottajia oli kyselyn toteuttamishetkellä yhteensä 27. Palveluntuottajista 26 vastasi kyselyyn, eli yhdeltä palveluntuottajalta ei saatu kyselyyn vastausta. Kultakin palveluntuottajalta sai kertyä yksi vastaus kyselyyn eli joko ryhmän yhteinen vastaus tai yhden henkilön vastaus. Suurin osa palveluntuottajista oli vastannut 2-5 hengen ryhmänä, ja viiden palveluntuottajan näkemystä edusti kutakin yksi työntekijä. Palveluntuottajien kysely sisälsi kumpaakin kuntoutusmuotoa koskevia kysymyksiä sekä kysymyksiä, joissa vastattiin kohdentaen vastaus laitosmuotoiseen tai avomuotoiseen kuntoutukseen. Palveluntuottajista 13 oli arvioinut sekä laitos- että avomuotoista kuntoutusta, kymmenen ainoastaan laitosmuotoista kuntoutusta ja kolme ainoastaan avomuotoista kuntoutusta. Näin ollen 23 palveluntuottajaa oli arvioinut laitosmuotoista kuntoutusta ja vastaavasti avomuotoista kuntoutusta 15 palveluntuottajaa.

Kuntoutujien ja palveluntuottajien ryhmähaastattelut toteutettiin kaikilla viidellä yliopistosairaalan erityisvastuualueella, kullakin alueella toteutui kaksi kuntoutujien ja palveluntuottajien ryhmähaastattelua. Ryhmähaastattelut toteutettiin kuntoutuskurssin lopulla, laitosmuotoisessa kuntoutuksessa viimeisellä kuntoutusjaksolla ja avomuotoisessa viimeisten tapaamispäivien aikana. Ryhmähaastatteluihin osallistui 81 kuntoutujaa. Haastattelua tehtäessä kuntoutujat olivat toisilleen jo tuttuja ja heillä oli haastattelua ajatellen riittävästi yhteisiä kokemuksia, kun kuntoutus oli ollut ryhmämuotoista. Palveluntuottajien haastatteluryhmät muodostuivat niistä moniammatillisista tiimeistä, jotka kuntoutuslaitoksissa toteuttivat tules-kuntoutusta. Haastattelutilanteissa oli kaksi tutkijaa haastattelemassa, haastattelut nauhoitettiin ja tallenteet litteroitiin litterointipalvelussa. Ryhmähaastattelussa haastateltavat tuottivat omien yksilöllisten käsitystensä kautta yhteisesti jaettua ymmärrystä (Pietilä 2017) tules-kuntoutuksesta ja siihen liittyneestä tavoitetyöskentelystä (haastattelurungot ks. tarkemmin Karhula ym. 2019, liite 7 ja 8).

Ryhmähaastatteluihin osallistuneista kuntoutujista 75 antoi luvan käyttää heidän GAS-tavoitelomakkeitaan (kuntoutujan omat tavoitteet -lomaketta) aineistona. Heistä 32 (37\%) oli osallistunut avomuotoiseen kuntoutukseen ja 43 (57 \%) laitosmuotoiseen kuntoutukseen.

Haastatteluaineisto analysoitiin sisällön analyysin keinoin (Krippendorff 2012). Litteroitu haastatteluaineisto jäsenneltiin tutkimuskysymysten mukaisiin teema-alueisiin. Teemoihin liittyvät olennaiset ilmaukset pilkottiin pelkistetyiksi ilmaisuiksi, jotka ryhmiteltiin teema-alueiden sisällä alaluokkiin. Abstrahoinnissa muodostettiin yläluokkia kokoamalla ja yhdistelemällä alaluokkia ja asiakokonaisuuksia toisiinsa. Kyselyaineistojen määrällinen aineisto analysoitiin tilastollisin menetelmin SPSS-ohjelmalla. Kuvaileva tieto kuntoutujien ja palveluntuottajien näkemyksistä esitettiin suorina jakaumina.

Kuntoutujan omat tavoitteet -lomakeaineisto analysoitiin teoriaohjaavalla lähestymistavalla, jossa ohjaavana teoriana oli ICF-luokitus. Kuntoutuksen tutkimuksen vakiintuneen käytännön mukaan tavoitteet sillattiin ICF-luokitukseen soveltaen Ciezan ja kumppaneiden (2002 ja 2005) kuvaamia siltausohjeita. Tavoitteesta eriteltiin merkityksellisenä käsitteenä asia tai teema, joka sillattiin ICF-luokituksen pääluokkaan ja tarkempaan koodiin. Tavoitteen saavuttamista arvioitiin laskemalla kuntoutujien tavoitteiden saavuttamisen T-lukuarvot sekä niiden keskiarvo ja hajonta. Kunkin kuntoutujan lomakkeista poimittiin tiedot tavoitteiden saavuttamisen arvioista. Kuntoutujan asettamien tavoitteiden (maksimissaan kolme tavoitetta) lukuarvot laskettiin yhteen ja muunnettiin T-lukuarvoksi taulukon perusteella (ks. Sukula ym. 2015). T-lukuarvoa tulkitaan niin, että tavoitteet ovat to- 
teutuneet odotusten mukaisesti silloin, kun T-lukuarvo on lähellä lukua 50, odotettua paremmin, kun T-lukuarvo on yli 50, ja odotettua heikommin, kun T-lukuarvo on alle 50 (Kiresuk \&t Sherman 1968).

\section{Tulokset}

\section{Tules-kuntoutuskurssien tavoitteiden asettaminen ja kohdentuminen}

Haastatteluaineistojen perusteella tavoitteiden asettamista pidetään tärkeänä. Palveluntuottajat kuvasivat, että oman tavoitteen asettaminen lisäsi kuntoutujien sitoutumista ja loi päämäärän kuntoutus- ja kuntoutumisprosesseille. Samalla arveltiin, että osa kuntoutujista muotoili tavoitteen ilman tarkempaa harkintaa. Yksilöllisten tavoitteiden tunnistaminen kuvattiin prosessina, johon liittyi seuraavia toimintatapoja: tavoitteisiin orientoitumista kuntoutuksen alkaessa, omat tavoitteet -lomakkeen esittelemistä ja tavoitteita koskevan yleisen tiedon jakamista pienryhmätilanteissa, kuntoutujien ohjaamista miettimään tavoitteita itsenäisesti, tavoitteista keskustelemista eri ammattilaisten yksilö- ja ryhmätapaamisissa sekä tavoitteiden nimeämistä yhdessä.

Kuntoutujien haastattelujen perusteella vallitsevana kokemuksena oli tavoitteiden asettamisen työläys, vaikka yksittäisiä näkemyksiä oli myös tavoitteen asettamisen sujuvuudesta. Palveluntuottajien ohjausta ja tukea pidettiin tärkeänä tavoitteen asettamisessa. Tosin ohjaus oli jossain tilanteissa vähentänyt kuntoutujien vaikuttamismahdollisuuksia. Näin tapahtui silloin, kun oli annettu valmiita esimerkkilistoja tavoitteista, joista kuntoutujat olivat valinneet tavoitteet, tai oli ohjattu asettamaan toinen tavoite liikuntaan kohdentuvaksi ja toinen johonkin muuhun aiheeseen.

"Niin, kun mehän ajateltiin, et vaan piti jotain tavotteita keksii. Toinen piti olla liikunnallinen. Ja toinen joku muu. Se oli määritelty, joo.” $\mathrm{KH}^{1}$
"Niin, ja kaik oli ihan ulalla, kun sai sen paperin, et tavotteet, mitä? Sit, no annetaan viis esimerkkii, ja siin oli ravinto, liikunta, laihduttaminen, mitä siin oli. Ja niist viidest sit valittiin ihan. Se oli kun veikkaust, et minkä sä otat siit." KH9

\begin{abstract}
"Kun ne tavotteet siihen Kelan paperiin piti kirjata. Se on ehkä ollu kaikesta hankalinta, mutta sekin tehtiin pienryhmissä, et siinä oli kuitenkin ohjaaja, joka avas sitä kaavaketta ja neuvo, et kuinka se täytetään, ja mitä sinne laitetaan ja... Et niihin on kyllä sit saanu apua täältä.” КH8
\end{abstract}

"Olihan ne helppo asettaa sinne kaavioon, mut toinen asia on toteuttaa ne." KH2

Palveluntuottajat ja kuntoutujat puhuivat niukasti haastatteluissa ryhmätavoitteista. Kuntoutujien haastatteluiden muutamassa ilmaisussa kuvattiin, että ryhmänä oli juteltu, mutta varsinaista ryhmätavoitetta ei ollut. Näissä keskusteluissa arveltiin, että ei olisi ryhmätavoitetta tarvittukaan tai mietittiin, onko ryhmätavoitteen asettaminen edes mahdollista. Yhdessä ryhmähaastattelussa tuotiin esille, että ryhmän tavoitteena oli kipujen lieventyminen.
“En mäkään muista mitään [ryhmä- tavoitetta], et mikä semmonen ylipää- tään vois olla, kun kuitenkin ollaan yksilöitä, niin mikä se [ryhmätavoite] sitten vois olla." KH4

Ainoastaan kahdessa palveluntuottajien haastatteluissa keskusteltiin ryhmätavoitteista. Toinen kertoi, että ryhmätavoitteet asetetaan heti kuntoutusprosessin alussa ja niillä nähtiin olevan merkitystä vertaistuen muodostumiseen. Toinen kuvasi, että ryhmätavoitteista kivunhallintaan liittyvä tavoite on ollut yleisin. Lisäksi harrastuksen

1) Haastattelulainauksissa käytetään seuraavia merkintöjä kuvaamaan lähdettä:

$K H=$ kuntoutujien haastattelu

PH = palveluntuottajien haastattelu 
Taulukko 2. Kuntoutujien omat tavoitteet sillattuina ICF-luokitukseen.

\begin{tabular}{|c|c|c|c|}
\hline ICF-pääluokka & Alaluokka (n) & $\begin{array}{l}\text { Esimerkkejä kuntoutujien omista } \\
\text { tavoitteista (indikaattori) }\end{array}$ & \begin{tabular}{|l} 
Tavoit- \\
teet \\
n (\%)
\end{tabular} \\
\hline $\begin{array}{l}\text { Ruumiin/ kehon } \\
\text { toiminnot }\end{array}$ & & & $98(61)$ \\
\hline $\begin{array}{l}\text { PL I Mielen- } \\
\text { toiminnot }\end{array}$ & $\begin{array}{l}\text { BI34 Unitoiminnot }(7) \\
\text { BI800 Itsen kokeminen (2) } \\
\text { BI30I Motivaatio (I) }\end{array}$ & \begin{tabular}{|l} 
*Unen laadun parantaminen \\
(nukahtamiskeinot ja unen levollisuus) \\
*Nukkuminen (tuntia yössä)
\end{tabular} & $10(6)$ \\
\hline $\begin{array}{l}\text { PL } 2 \\
\text { Aistitoiminnot ja } \\
\text { kipu }\end{array}$ & B280 Kipuaistimus (9) & $\begin{array}{l}\text { *Alaselän kipujen vähentyminen (kipujana) } \\
\text { *Niskan kipujen hallinta (harjoittelumäärät } \\
\text { viikossa) }\end{array}$ & $9(6)$ \\
\hline $\begin{array}{l}\text { PL } 5 \\
\text { Ruoansulatus-, } \\
\text { aineenvaihdunta- ja } \\
\text { umpieritysjärjestel- } \\
\text { män toiminnot }\end{array}$ & $\begin{array}{l}\text { B530 Painonhallinta- } \\
\text { toiminnot }(28)\end{array}$ & $\begin{array}{l}\text { *Painonhallinta (aterioiden useus) } \\
\text { *Painonhallinta (pudotetut kilomäärät) } \\
\text { *Painonpudotus, terveysriskien } \\
\text { vähentäminen (pudotetut kilomäärät) }\end{array}$ & $28(18)$ \\
\hline $\begin{array}{l}\text { PL } 7 \\
\text { Tuki- ja liikunta- } \\
\text { elimistöön ja } \\
\text { liikkeisiin liittyvät } \\
\text { toiminnot }\end{array}$ & \begin{tabular}{|l|} 
B7I0 Nivelten \\
liikkuvuustoiminnot (19) \\
B730 Lihasvoiman ja tehon \\
tuottotoiminnot $(31)$ \\
B740 \\
Lihaskestävyystoiminnot \\
(I)
\end{tabular} & \begin{tabular}{|l|} 
*Tietoa ja menetelmiä turvallisista \\
harjoitteista liikkuvuuden lisääntymiseksi \\
(ohjeiden saanti ja harjoitteiden tekeminen ja \\
oma kokemus liikkuvuuden lisääntymisestä) \\
*Liikkuvuuden säilyttäminen (venyttely ja \\
liikkuvuuden harjoittelukerrat viikossa) \\
*Lihaskunnon lisääminen (harjoittelun määrä \\
viikossa) \\
*Fyysisesti parempi kunto (lihaskuntotestin \\
tulokset)
\end{tabular} & $51(32)$ \\
\hline $\begin{array}{l}\text { Suoritukset ja } \\
\text { osallistuminen }\end{array}$ & & & $59(37)$ \\
\hline $\begin{array}{l}\text { PL I } \\
\text { Oppiminen }\end{array}$ & $\begin{array}{l}\text { DI38 Tiedon } \\
\text { omaksuminen (I) }\end{array}$ & $\begin{array}{l}\text { *Tiedon lisääntyminen, mitä voin tehdä } \\
\text { (ohjeiden saaminen, harjoitteiden } \\
\text { tekeminen, notkeus lisääntynyt) }\end{array}$ & I (I) \\
\hline $\begin{array}{l}\text { PL } 2 \text { Yleisluonteiset } \\
\text { tehtävät ja vaateet }\end{array}$ & $\begin{array}{l}\text { D } 240 \text { Stressin ja muiden } \\
\text { psyykkisten vaateiden } \\
\text { käsitteleminen (I) }\end{array}$ & $\begin{array}{l}\text { * Stressin ja työkuormituksen vähentäminen } \\
\text { (työtehtävistä kieltäytyminen) }\end{array}$ & I (I) \\
\hline $\begin{array}{l}\text { PL } 5 \text { Itsestä } \\
\text { huolehtiminen }\end{array}$ & $\begin{array}{l}\text { D } 570 \text { I Ruokavaliosta ja } \\
\text { fyysisestä kunnosta } \\
\text { huolehtiminen (46) } \\
\text { D } 5702 \text { Oman terveyden } \\
\text { ylläpitäminen (3) }\end{array}$ & $\begin{array}{l}\text { *Liikunnan säännöllisyys (liikkumisen määrä } \\
\text { viikossa) } \\
\text { *Ravitsemus kuntoon (herkkupäivien määrä } \\
\text { viikossa, kuukaudessa) }\end{array}$ & $49(31)$ \\
\hline $\begin{array}{l}\text { PL } 7 \text { Henkilöiden } \\
\text { välinen vuorovaiku- } \\
\text { tus ja ihmissuhteet }\end{array}$ & $\begin{array}{l}\text { D } 750 \text { Vapaamuotoiset } \\
\text { sosiaaliset ihmissuhteet (I) }\end{array}$ & $\begin{array}{l}\text { *Sosiaalisen verkoston "ylläpito" (kontaktien } \\
\text { määrä kuukaudessa) }\end{array}$ & $I(I)$ \\
\hline $\begin{array}{l}\mathrm{PL} 8 \text { Keskeiset } \\
\text { elämänalueet }\end{array}$ & $\begin{array}{l}\text { D } 850 \text { Vastikkeellinen työ } \\
\text { (7) }\end{array}$ & $\begin{array}{l}\text { *Työhonpaluun sujuminen turvallisesti } \\
\text { (työtehtävien muokkaaminen) } \\
\text { *Työn suunnittelu siten, että se tukee myös } \\
\text { vapaa-ajan jaksamista (työn keventäminen, } \\
\text { jaksamisen lisääntyminen) } \\
\text { *Työssä jaksamisen parantuminen, motivaa- } \\
\text { tion lisääntyminen (kuvailu parantumisesta) }\end{array}$ & $7(4)$ \\
\hline Ympäristötekijät & & & $2(I)$ \\
\hline $\begin{array}{l}\text { PLI Tuotteet ja } \\
\text { teknologiat }\end{array}$ & $\begin{array}{l}\text { E I35 Työssä käytettävät } \\
\text { tuotteet ja teknologiat (2) }\end{array}$ & *Ergonomia työssä (päivää viikossa) & $2(1)$ \\
\hline Ruumiin rakenne & & & I (I) \\
\hline $\begin{array}{l}\text { PL } 7 \text { Liikkeeseen } \\
\text { liittyvät rakenteet }\end{array}$ & $\begin{array}{l}\text { S770 Liikkeeseen liittyvät } \\
\text { rakenteet (I) }\end{array}$ & *Vyötärömitan pienentäminen $(\mathrm{cm})$ & $I(I)$ \\
\hline Yhteensä & & & 160 \\
\hline
\end{tabular}


tai uuden liikuntamuodon löytämiseen tai kokeiluun ja joskus myös mielenterveyden tukemiseen oli palveluntuottajan mukaan asetettu ryhmätavoitteita.

Kuntoutujat omat tavoitteet -lomakkeiden $(n=75)$ tarkastelu osoitti, että tavoitteista $(\mathrm{n}=161)$ suurin osa, 61 prosenttia, kohdistui ICF-luokituksen mukaiselle ruumiin ja kehon toiminnot -osa-alueelle. Suoritukset ja osallistuminen -osa-alueen tavoitteista (37 prosenttia kaikista tavoitteista) yleisimpiä olivat itsestä huolehtimisen pääluokan 5 ”D5701 Ruokavaliosta ja fyysisestä kunnosta huolehtiminen" -alaluokan tavoitteet. Nämä liittyivät esimerkiksi liikunnan lisäämiseen ja säännöllisemmäksi muuttamiseen sekä ruokarytmiin tai ruokavalioon.

Tarkastellut lomakkeet nostivat esille myös tavoitteiden muotoilun haasteet. Yhtenä usein esiintyvänä haasteena oli se, että tavoitteiden indikaattoreina oli käytetty menetelmiä tavoitteeseen pääsemiseksi, ja näin tavoitetasot eivät välttämättä antaneet tietoa tavoitteen saavuttamisesta. Esimerkiksi kun tavoitteena oli lihasvoiman lisääminen, indikaattoriksi oli asetettu lihasvoimaharjoitteiden määrä, joka ei suoraan kerro sitä, onko lihasvoima lisääntynyt. (Taulukko 2.)

Tutkimusaineistojen perusteella tavoitteiden nivoutuminen työelämään on ohutta, vaikka palvelukuvauksessa työkyvyn edistäminen on tules-kuntoutuksen yleisenä ta- voitteena. Haastatteluissa puhuttiin niukasti työkyvyn ja työelämän tukemisesta. Tavoitteista ainoastaan neljä prosenttia oli linkitettävissä työelämään. Omat tavoitteet -lomakkeissa työelämään liittyviä tavoitteita $(n=7)$ olivat esimerkiksi työssä jaksaminen, työhön palaaminen sekä työn suunnittelu siten, että se tukee myös vapaa-ajan jaksamista. Työympäristön ergonomiaan liittyviä tavoitteita oli asettanut kaksi kuntoutujaa. (Taulukko 2.)

\section{Tavoitteet kuntoutusta ja kuntoutumista ohjaamassa}

Haastattelu- ja lomakeaineistojen perusteella tules-kuntoutuksessa kuntoutujan omien, yksilöllisten tavoitteiden asettaminen ja niiden saavuttamisen arviointi kuntoutusprosessin päätteeksi on tavanomainen käytäntö. Tavoitteet koetaan tärkeäksi osaksi kuntoutusprosessia. Tavoitteiden väliarvioinnit oli toteutettu noin kahdessa kolmasosassa lomakkeista. Sen sijaan lomakkeissa tavoitteiden sisältöjä ei ollut korjattu tai tarkennettu lainkaan kuntoutusprosessin kuluessa.

”Alussahan ei voinu tietää, että sitä lyö
jonku tavoitteen. Musta se olis oikeen
hyväkin tämä näin, että kun eihän sitä
voi tietää, että mitä se on sitten käytän-
nössä, että puolivälissä vois kattoa, että
oliko tää hyvä tavoite. Tällaista keskus-

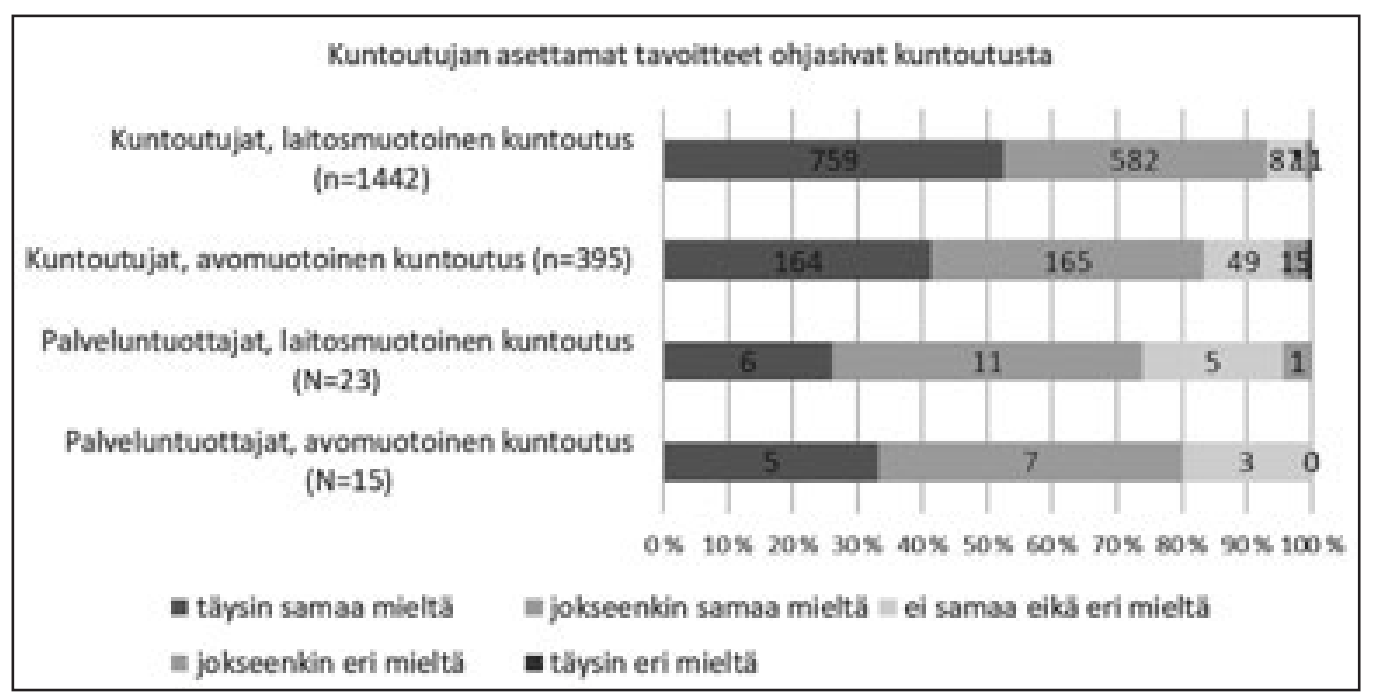

Kuvio 2. Kuntoutujan ja palveluntuottajien arviot siitä, missä määrin kuntoutujan tavoitteet ohjaavat kuntoutusta. 
telua vois käydä siinä - kun sä oot testannu, jos sä nyt tekisit uudet tavoitteet, niin mitkä ne olis.” KH4

Kyselyissä kuntoutujat arvioivat useammin kuin palveluntuottajat, että kuntoutujien omat tavoitteet ohjaavat kuntoutusta. Ero arvioissa on näkyvissä etenkin laitosmuotoisessa kuntoutuksessa. (Kuvio 2.)

Myös palveluntuottajat korostivat haastatteluissa kuntoutujien oman toiminnan tärkeyttä sekä samanaikaisesti myös omaa rooliaan muutokseen motivoijina ja realistisen etenemisen tukijoina. Palveluntuottajien mukaan pyrkimykset tukea kuntoutujaa hänen toimintansa suuntaamisessa tukevat tavoitteen saavuttamista, vaikka he tunnistavatkin tavoitteen jäävän ajoittain irralliseksi kuntoutuksesta.

"Mä itse nään koko ajan työssäni sen muutoksen. Mitä pienempiä asioita ihmisen saa muuttamaan, ni se on sitä parempi. Et mä en yritäkkään muuttaa ihmisissä isoa asiaa, vaan pienin askelin, ni se lähtee viemään sitä ihmistä ite eteenpäin. Ku se on itsellekkin vaikeeta, ni sehän on sitten ihmisille vaikeeta. Ei puhuta kokoajan vaan tällasista yleisistä asioista, vaan mitä se on valmis ite tekemään.” РН8

"Ja jääkö se irtonaiseksi sit loppupeleissä kuitenkin siitä kuntoutuksesta tämä tavote, että se on ehkä se sellanen mihin ite yrittäny kiinnittää huomiota enemmän ku on oppinu vähän että -heitä pitää muistuttaa että ne tavotteet, jotka ollaan kirjattu, et ne on ne tärkeet jutut, mihin tän koko kuntoutuksen pitäs niihin vaikuttaa. Et ehkä aluks silloin ei se oma ohjeistuskaan välttämättä oo ollu niin semmonen tarkka, että tää on nyt todella sellanen punanen lanka tässä kuntoutuksessa." PH4

\section{Tavoitteiden saavuttaminen}

Tavoitteen saavuttamisen loppuarviointi oli tehty lähes kaikille kuntoutujille, yhdestä lomakkeesta 75:stä puuttui loppuarvio. Avomuotoiseen kuntoutukseen osallistuneet kuntoutujat saavuttivat tavoitteensa keskimäärin hieman odotettua tasoa heikommin, T-lukuarvo oli 46 ja keskihajonta 11. Laitosmuotoiseen kuntoutukseen osallistuneet kuntoutujat saavuttivat tavoitteensa keskimäärin odotetun tasoisesti, T-lukuarvo oli 49 ja keskihajonta 10. (Kuvio 3.)

Tutkimuksessa ei systemaattisesti selvi-

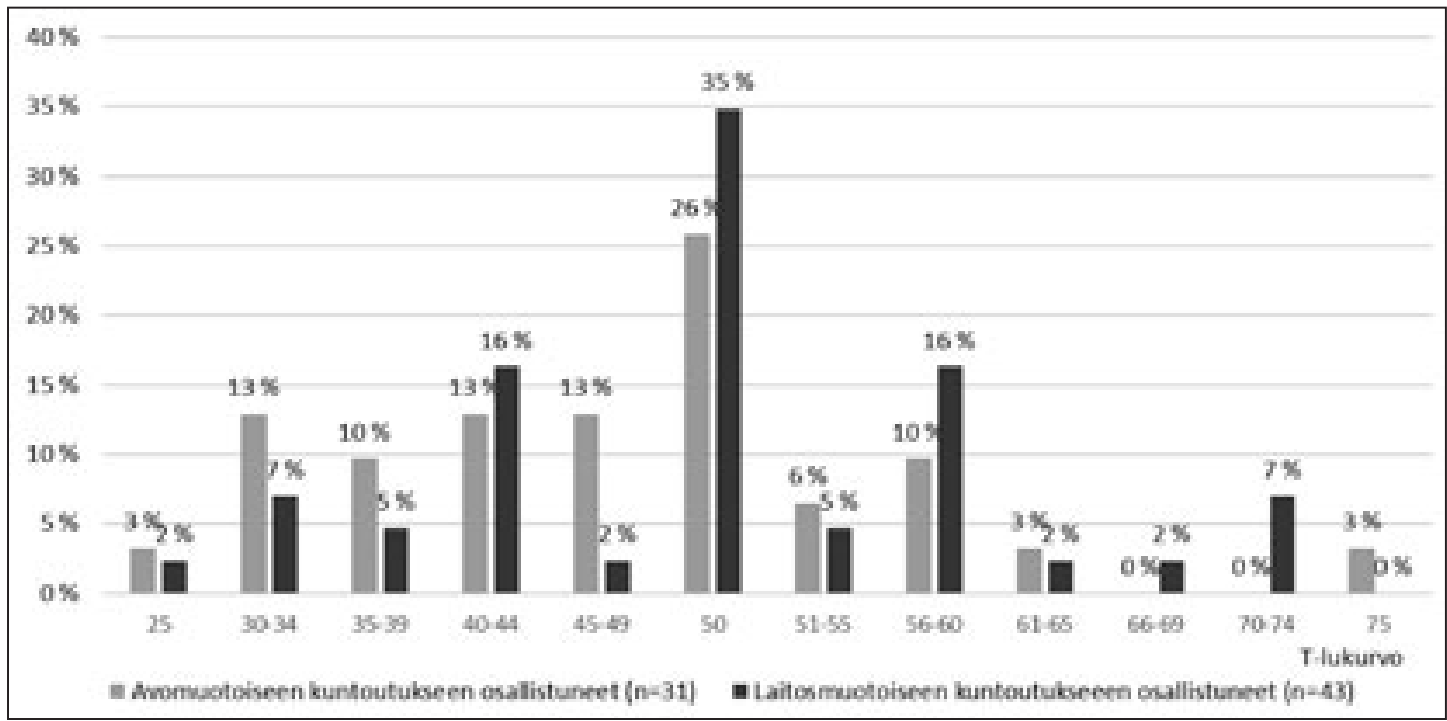

Kuvio 3. GAS-tavoitteen saavuttamisen T-lukuarvot tarkasteltuina erikseen laitosmuotoiseen ja avomuotoiseen kuntoutukseen osallistuneilla kuntoutujilla. 
tetty tavoitteen saavuttamiseen vaikuttavia tekijöitä. Yhtenä mahdollisena tavoitteen saavuttamiseen vaikuttavana tekijänä voidaan nähdä se, että kuntoutujan omat tavoitteet eivät olleet aina kurssin koko henkilöstön tiedossa. Noin puolet laitosmuotoiseen kuntoutukseen osallistuneista kuntoutujista (56 \%) ja laitosmuotoisen kuntoutuksen palveluntuottajista (57 \%) arvioi, että tavoitteet olivat kurssin koko henkilöstön tiedossa. Vastaavasti avomuotoisessa kuntoutuksessa kuntoutujista reilusti alle puolet (40\%) ja palveluntuottajista vain kolmasosa (33 \%) arvioi näin. Kyselyiden perusteella kuntoutuksen sisällöt eivät aina vastaa tavoitteisiin, mikä korostui avomuotoisessa kuntoutuksessa. Täysin samaa mieltä väittämän "Kuntoutuksen sisällöt auttavat etenemään tavoitteissa" oli 20 prosenttia avomuotoisen kuntoutuksen palveluntuottajista ja 27 prosenttia kuntoutujista.

Kuntoutujat pohtivat haastatteluissa myös asettamansa tavoitteen realistisuutta. He toivat esille, että muutokseen tarvittavan ajan ja panostuksen määrä selkiytyi ja konkretisoitui kuntoutuksen kuluessa. Tämän vuoksi alussa asetettu tavoite saattoi tuntua liian vaativalta, kun sitä tarkasteli kuntoutuksen loppuvaiheessa.

"Mä laitoin vähän yläkanttiin sen toisen tavotteen. Se ehkä vähän tuli yllätyksenä, et kuinka pitkän ajan kuitenkin se muutoksen tekeminen vie. Et se vaatii aika pitkän ajan, et sä pääset siihen tavotteeseen." KH8

Tavoite kuvattiin muutosprosessin välineenä, jolloin kuntoutujan oma näkemys tavoitteen saavuttamisesta oli kuntoutumisprosessin olennainen osa. Tavoitteen saavuttamisen tarkastelu kuntoutuskurssin lopussa antoi tietoa kurssin jälkeiseen työskentelyyn eli asetettu tavoite ei ollut ainoastaan kurssia varten.

"Just sekin on tullu mun mielestä täällä hyvin, että vaikket sää pääsis niihin... Ni ei se tarkota sitä, että sä nyt... Ettet sä enää teekkään. Vaan se on ollu se välivaihe, et sä et oo jostaa syystä pystynny ja sit mennään eteenpäin taas. Että tämmöstä kaikki on kyllä tuonu ihan hyvin esiin. Että ittelleen siitä tavallaa armeliaisuutta... Omaa vähän itsekkyyttäkin ottaa jonkun asioitten suhteen. Ja kaikki tavotteisiin ja muihin pääsemiseksi." КН8

”Oli hyvä se että niissä on eri asteita mitä saavuttaa, vaan mä pääsin, että mä sain osan siitä, että se ei ollu tämmönen joko/tai-tavoite, että tossa on toi raja, että jos jää alle niin olet epäonnistunut... ei tuu semmosta fiilistä.” KH4

"Mut ei kyl tota keinojuttua, et millä keinoilla mä todennäköisemmin voisin saada, niin ehkä semmonen keskustelu oli vähäisempää siinä, et se vois olla ihan hyvä juttu siinä, tätä tavotejuttua ajatteli jotenkin sillain että kun tää on niin pitkä prosessi.” KH4

\section{Pohdinta}

Tutkimuksen tulokset vahvistavat sitä yleistä näkemystä, että tavoitetyöskentely on vakiintunut osaksi tules-kuntoutuskursseja. Kuitenkin tulisi entistäkin enemmän keskittyä kuntoutujan omaan arkeen ja elämäntilanteeseen sekä erityisesti hänen itse tunnistamiinsa muutostarpeisiin. Vahvistusta sai myös se aiempien tutkimusten näkemys, että GAS-menetelmä voi parhaimmillaan olla toimiva kuntoutujan ja ammattilaisen yhteinen väline, joka selkeyttää kuntoutujan omaa toimintaa kuntoutusprosessissa (vrt. Sipari ym. 2019, Sallinen ym. 2015). Tämän tutkimuksen tulokset osoittavat, että kuntoutujan omien tavoitteiden nimeäminen ja ammattilaisen näkemys kuntoutumisen kannalta olennaisesta tavoitteesta eivät aina kohtaa. Myös Saiton ja kumppaneiden (2019) tutkimuksen perusteella kuntoutujien ja ammattilaisten näkemykset tavoitteista ovat erilaiset, mikä saattaa johtaa näkemyksellisiin eroihin myös tarvittavista kuntoutustoimenpiteistä.

Tulokset osoittivat, että tules-kuntoutuskursseilla ei laadita systemaattisesti ryhmäkohtaisia tavoitteita. Jatkossa on tarpeen pohtia, mikä ryhmäkohtaisten tavoitteiden merkitys on. Niiden merkitys olisi tärkeää 
havainnollistaa kuntoutusryhmälle ja liittää tavoitteet selkeästi ryhmän tarpeisiin ja toiveisiin. Zhang ja Chiu (2011) ehdottavat, että ryhmäläisten omat tavoitteet annettaisiin muiden ryhmäläisten tietoon, jolloin ryhmään samaistuminen vahvistuisi. Ryhmätyöskentelyyn sitoutuminen vahvistuu, kun ryhmäläiset saavat selkeämmän käsityksen ryhmän tavoitteiden ja työskentelyn liittymisestä omiin henkilökohtaisiin tavoitteisiin (Zhang \&t Chiu 2011). Lisäksi olisi tärkeää keskustella siitä, miten ryhmän tavoitteet liittyvät henkilökohtaisiin tavoitteisiin ja tukevat samalla jokaisen tules-kuntoutujan omaa kuntoutumisen prosessia.

Tämän tutkimuksen tulokset ovat yhteneväiset Ylisassin ja kumppaneiden (2018) tutkimuksen tulosten kanssa siinä, että tules-kuntoutuksessa tavoitteiden painopiste on vahvasti fyysisissä tavoitteissa ja työelämään liittyviä tavoitteita nimetään vähäisesti tules-kuntoutuksessa. Myös Reiterä ja kumppanit (2019, s 49-53) ovat todenneet, että fyysisen terveyden edistäminen ja siihen liittyvien tavoitteiden laatiminen ovat muita hyvinvoinnin ja elämänlaadun osa-alueita vahvemmin esillä kuntoutuksessa. Tämän tutkimuksen tulokset vahvistavat Huttingin ja kumppaneiden (2017) esille tuomaa tarvetta vahvistaa tules-kuntoutuksen työelämäyhteyttä. Tulisi kehittää yhteistyötä kuntoutuksen ja työterveyshuollon henkilöstön välillä sekä lisätä kuntoutushenkilöstön ymmärrystä kuntoutujan työhön osallistumiseen liittyvistä tekijöistä (mm. työn sisällöistä, fyysistä ja psykologisista vaatimuksista, työn merkityksestä kuntoutujalle sekä työkyvyttömyyden ehdoista) (Hutting ym 2017).

Tutkimusjoukko saavutti kuntoutuksen tavoitteet odotetun tasoisesti. Tämä on linjassa aiempien tutkimusten tulosten kanssa, joissa on osoitettu moniammatillisella, alaselkäoireisiin tähtäävällä tules-kuntoutuksella olevan positiivisia vaikutuksia muun muassa kivun ja vammaisuuden kokemiseen sekä työhön (Kamper ym. 2014). Kuitenkin merkille pantavaa on, että avomuotoisessa tules-kuntoutuksessa tavoitteiden saavuttaminen oli heikompaa verrattuna laitosmuotoiseen kuntoutukseen. Tämä selittynee osittain sillä, että avomuotoinen kuntoutus on kehittymässä oleva, vuonna 2016 käynnistetty uusi palvelumuoto. Avomuotoinen kuntoutus antaa uudenlaisen mahdollisuuden rakentaa tavoitetyöskentelyn prosessin joustavaksi kuntoutustapaamisten ja työelämän vuorottelun mukaisesti, minkä vuoksi avomuotoisen kuntoutuksen tutkiminen olisi jatkossa tärkeää.

Tulosten perusteella sekä kuntoutujat että palveluntuottajat näkevät kuntoutujan omien tavoitteiden asettamisen kuntoutumisprosessin tärkeäksi osaksi. Tämän tutkimuksen tulokset ovat yhdenmukaiset Siparin ja kumppaneiden (2019) tutkimuksen kanssa siinä, että palveluntuottajien näkökulmasta tavoitteen asettaminen voidaan nähdä kuntoutujan oppimisprosessina, joka vaatii aikaa ja ammattilaisen tukea. Kuitenkin tulokset antavat viitteitä siitä, että kuntoutujan kuntoutumisprosessi ja kuntoutuksen ammattilaisjohtoiset toimenpiteet eivät aina kohtaa, vaan ne kulkevat rinnakkain ja ajoittain risteävät. Kuntoutuksen tavoitteiden ammattilaisjohtoisuus on tullut esille myös aiemmissa tutkimuksessa (Rose ym. 2017, Rose ym. 2019, Saito 2019).

Tämä tutkimus nostaa tarpeen kehittää kuntoutujan omien toiveiden mukaisia ja samalla realististen tavoitteiden nimeämisen käytäntöjä. Esimerkiksi Siparin ja kumppaneiden (2019) tutkimuksessa todettiin, että GAS-menetelmän mukainen tavoite ei aina ohjaa kuntoutujan omaa toimintaa. Myös Reiterä ja kumppanit (2019, 49-53) korostavat realististen tavoitteiden merkitystä. Onkin tärkeää pysähtyä pohtimaan, miten tavoitteita nimetään ja millainen tavoite voi ohjata kuntoutumisen prosessia. Saito ja kumppanit (2019) ehdottavat kuntoutuksen tavoitteiden painottamista työhön, vapaa-ajan toimintoihin ja yhteisöön osallistumiseen - nykyisten kehontoimintoihin ja päivittäisiin perustoimintoihin keskittyvien tavoitteiden sijaan.

Olisiko nyt aika ottaa loikka spesifeistä ja mitattavista (SMART) kuntoutuksen tavoitteista kohti tavoitteiden merkityksellisyyttä (MEANING-periaate) (McPherson ym. 2015, 12-14)? MEANING-periaatteen avulla tavoitetyöskentely voisi konkretisoitua 
kuntoutujalle omaan kuntoutumisprosessiin yhdistettäväksi. Samalla tavoin myös jaetun päätöksenteon ideat tulisi siirtää aktiiviseksi toiminnaksi. Näin kuntoutujien mahdollisuus osallistua tavoitteen asettamiseen vahvistuisi (Rose ym. 2017, Rose ym. 2019) ja kuntoutujien kanssa yhdessä laaditut tavoitteet lisäisivät heidän motivoitumistaan ja sitoutumistaan työskentelyyn (Reiterä ym. 2019, 49-53).

Tavoitetyöskentelyssä on tärkeää, että ammattilaisella ja kuntoutujalla on yhteinen ymmärrys kuntoutujan elämäntavoitteista ja -arvoista, joihin kuntoutuksen tavoitteet yhdistyvät. Apuna voi käyttää esimerkiksi kuntoutujalle ennakkoon tutustuttavaksi annettavaa tavoitteenasettamista käsittelevää materiaalia (Rose ym. 2019), strukturoituja tiedonkeruumenetelmiä kuten Canadian Occupational Performance Measure -haastattelua (Saito ym. 2019) ja motivoivan haastattelun keinoja (Veijola ym. 2015). Kun kuntoutuksen tavoitteet luontevasti yhdistyvät kuntoutujan elämäntavoitteisiin, kuntoutujan on helpompi ymmärtää kuntoutus osaksi arkielämää ja tavoitteisiin sitoutuminen vahvistuu (Dekker 2020, Karhula ym. 2016). Tules-kuntoutuksessa tavoitellaan pysyvää muutosta kuntoutujan käyttäytymisessä, jolloin kuntoutuksen vaikutukset näkyvät arkielämässä vahvistaen toiminta- ja työkykyä.

Monimenetelmällisen tutkimuksen luotettavuutta arvioitaessa on tarpeen tarkastella muun muassa kerättyjen määrällisten ja laadullisten tutkimusaineistojen suhdetta tutkimuskysymykseen sekä eri menetelmillä kerättyjen ja analysoitujen tulosten integrointia (Cresswell \& Plano Clark 2018, 216221). Eri aineistot onnistuttiin keräämään alueellinen kattavuus huomioiden ja siinä laajuudessa kuin oli suunniteltu. Ainoastaan kuntoutujien kyselyn kokonaisvastausprosentti jäi heikoksi johtuen palveluntuottajakohtaisista vaihteluista vastausprosenteissa. Kyselyt kuitenkin mahdollistivat suuren kuntoutujajoukon ja lähes kaikkien palveluntuottajien näkemysten selville saamisen. Vastaavasti haastattelut antoivat sekä kuntoutujille että palveluntuottajille mahdollisuuden kertoa syvemmin kokemuksistaan ja heille tärkeistä näkökulmista (vrt. Hyvärinen
2017, Luomanen \& Nikander 2017). Kahden tutkijan läsnäolo vahvisti haastattelujen luotettavuutta ja mahdollisti haastattelutilanteiden reflektoinnin ja havaintojen vertaamisen analyysin ja synteesin edetessä.

Runsaan moninäkökulmaisen ja tutkittavien erilaisia intressejä sisältäneen aineiston analyysissa ja synteesissä haasteellisinta oli monimutkaista kokonaisuutta koskevan aineiston yhdistäminen johtopäätöksiksi (vrt. Seppänen-Järvelä ym. 2019). Tutkimusryhmä teki tiivistä yhteistyötä, keskusteli eriävistä näkemyksistä ja tarvittaessa palasi alkuperäiseen aineistoon, mikä vahvisti tutkimusaineistosta tehtyjen tulkintojen ja päätelmien luotettavuutta. Tutkimuksen etenemisestä raportoitiin tutkimusta ohjanneelle asiantuntijaryhmälle Kelassa tutkimushankkeen edetessä. Sormusen ja kumppaneiden (2013) mukaan monimenetelmällistä tutkimuksen laatua on arvioitava myös hyödynnettävyyden näkökulmasta. Tämä tutkimus vastasi Kelan kuntoutuksen kehittämistarpeisiin, ja tutkimuksen johtopäätöksiä on voitu soveltaa Kelan kuntoutuksen kehittämisessä, kuten vuonna 2020 voimaan tulleissa tules-kuntoutuksen palvelukuvauksissa.

Aidosti asiakaslähtöinen lähestymistapa vaatii ammattilaisilta monenlaista osaamista. Jatkossa olisi tarve kiinnittää huomiota ammattilaisten jaetun päätöksenteon osaamiseen, jotta he pystyisivät parhaalla mahdollisella tavalla osallistamaan kuntoutujia tavoitteiden asettelun prosessiin. Ammattilaisten kouluttaminen GAS-menetelmän käyttöön sekä jaetun päätöksenteon työskentelytapaan vahvistavat tavoitteiden arki- ja työelämälähtöisyyttä sekä asiakkaan motivoitumista ja osallistumista (Rose ym. 2019, Sallinen ym. 2015, 36-39).

Tavoite on kuntoutuksen suunnittelun näkökulmasta olennaisin osa kuntoutuksen prosessia. Tutkimus herättää kysymään, minkä muotoiset tavoitteet ja millaiset tavoitteen saavuttamista tukevat prosessit pitäisivät yllä kuntoutumisen motivaatiota ja varmistaisivat, että kuntoutujan kuntoutumisprosessi jatkuu arjen toimintana myös kuntoutusjakson jälkeen. Ei ole yksiselitteistä tapaa, miten kuntoutuksessa edetään tavoitteita kohti. Tavoitetyöskentelyn prosessi 
pitää selkeästi avata kuntoutujalle, jotta hän voi siihen osallistua, sitoutua ja siirtää kuntoutuksen tavoitteet osaksi omaa arkea, työelämää ja elämäntavoitteita.

\section{Tulosten merkitys: Tutkimuksessa} nousi esille suositeltavia toimintamalleja ja -käytäntöjä tavoitteiden asettamisen ja tavoitteen saavuttamisen edistämisen näkökulmasta. Tavoitteen realistisuutta on arvioitava prosessin aikana, ja tavoitetta on tarkistettava tarpeen mukaan. Kuntoutujaa tulisi ohjata asettamaan nykyistä selkeämmin työelämään nivoutuvia tavoitteita, joihin kuntoutustoimenpiteet vastaavat. Erilaiset kuntoutustoimenpiteet sekä kuntoutujan ohjattu oma työskentely on nivottava suoraan kuntoutujan omaan tavoitteeseen. Ammattilaiset tarvitsevat koulutusta ja säännöllistä osaamisen päivitystä GAS-tavoitteiden asetteluun.

\section{Tiivistelmä}

Kelan järjestämien tuki- ja liikuntaelinsairaus (tules) -kuntoutuskurssien toteutusta ja toimivuutta, asiakaslähtöisyyttä ja kuntoutujan roolia sekä kuntoutuksen vaikutuksia kuntoutujan arkeen tarkasteltiin Kelan MUUTOS-hankkeen tules-kuntoutuksen tutkimuksessa. Tässä artikkelissa syvennetään tutkimuksen yhtä keskeistä teemaa, kuntoutuksen ja kuntoutumisen tavoitteiden asettamista ja tavoitteen saavuttamista tukevaa kuntoutus- ja kuntoutumisprosessia. Artikkelin tavoitteena on kuvata, millaisia tavoitteita tules-kuntoutuksessa on, miten tavoitteet ohjaavat kuntoutusta ja kuntoutumista sekä miten hyvin tavoitteet saavutettiin kuntoutuksen aikana.

Monimenetelmällisen tutkimuksen aineistoina olivat kuntoutujille ja palveluntuottajille suunnatut kyselyt, kuntoutujien ja palveluntuottajien ryhmähaastattelut sekä kuntoutujien Omat tavoitteeni -lomakkeet. Kuntoutujien kyselyyn vastasi 1839 kuntoutujaa, joista laitosmuotoiseen kuntoutukseen oli osallistunut 1441 kuntoutujaa ja avomuotoiseen kuntoutuk- seen 398 kuntoutujaa. Palveluntuottajien kyselyyn vastasi 26 palveluntuottajaa. Kuntoutujien ja palveluntuottajien ryhmähaastatteluja toteutettiin molempia 10. Kuntoutujien omat tavoitteet -lomakkeita analysoitiin 75, ja niissä oli yhteensä 161 tavoitetta. Määrälliset ja laadulliset aineistot analysoitiin ensin erikseen ja tämän jälkeen teemoittain yhdistettiin ja luotiin monimenetelmällisen aineiston perusteella tulkinnat.

Tavoitteet painottuvat fyysisen toimintakyvyn edistämiseen, työelämään nivoutuvia tavoitteita asetetaan vähän. Tavoitteet ohjaavat kuntoutuskurssien sisältöjen rakentumista vaihtelevasti. Avomuotoiseen kuntoutukseen osallistuneet kuntoutujat saavuttivat tavoitteensa keskimäärin hieman heikommin (T-lukuarvo 46) kuin laitosmuotoiseen kuntoutukseen osallistujat (T-lukuarvo 49).

Tavoitteet koetaan tärkeäksi osaksi kuntoutusprosessia. Kuntoutujien omien tavoitteiden tulisi kuitenkin ohjata nykyistä selkeämmin kuntoutujien toimintaa koko kuntoutusprosessin ajan. Tavoitteiden työelämäyhteyttä tulisi vahvistaa, jotta kuntoutujien tavoitteet kiinnittyisivät vahvemmin työelämään ja tules-kuntoutuskurssit tukisivat työkykyä nykyistä enemmän.

Avainsanat: tules-kuntoutus, tavoitteet, monimenetelmällisyys, GAS-menetelmä

\section{Abstract}

Do client's own goals guide MDSs rehabilitation process?

The multi-perspective information on the implementation of Kela (the Social Insurance Institution of Finland)-provided musculoskeletal disorders (MSDs) rehabilitation courses, the client's role in the rehabilitation, and the effects of rehabilitation on the person's everyday life were produced in the MSDs rehabilitation study. This article deepens one theme of the study, the goals of the rehabilitation and the rehabilitation process, which sup- 
port achieving the goals. The aim of the article is to describe what kind of goals MDSs rehabilitation exist, how goals guide rehabilitation, and how goals were achieved during rehabilitation.

The study applied mixed methods and a multi-perspective approach. The data included questionnaires and group interviews of rehabilitees and rehabilitation professionals, combined with the rehabilitees' Goal Attainment Scale (GAS) forms. A total of 1,839 respondents answered the questionnaire for rehabilitees, with 1,441 respondents having taken part in inpatient rehabilitation and 398 in outpatient rehabilitation. The service providers' questionnaire yielded 26 responses. In addition, ten group interviews were conducted both with rehabilitees, and with service providers. A total of 75 personal goal forms were analysed, presenting 161 goals.

Promoting physical functioning was the most frequent goal, only few goals related to work life. There was variation of how the goals of the rehabilitation courses guide the content of the courses. The goals were achieved weaker in the outpatient rehabilitation (t-score 46) than in inpatient rehabilitation (t-score 49). Goal-oriented activities were considered important, but the rehabilitees' personal goals should better guide their own activities throughout the process. Furthermore, the connection of the rehabilitation to the working life should be strengthened. If the goals are linked more closely to work, they would support working capacity to a greater extent than currently.

Keywords: musculoskeletal disorders (MSDs) rehabilitation, Goal Attainment Scale, mixed methods, goals of the rehabilitation

\footnotetext{
Maarit Karhula, TtM, tutkimuspäällikkö,
} Kaakkois-Suomen Ammattikorkeakoulu

Tuija Heiskanen, TtM, tutkija, Kela

\section{Lähteet}

Autti-Rämö I, Salminen AL (2016) Kuntoutumisen hyvät käytännöt. Teoksessa I Autti-Rämö, A-L Salminen, M Rajavaara, A Ylinen (toim.) Kuntoutuminen. Duodecim, Helsinki.

Barnard RA, Cruice MN, Playford ED (2010) Strategies used in the pursuit of achievability during goal setting in rehabilitation. Qualitative Health Research 20, 2, 239-250.

Bovend'Eerdt TJ, Botell RE, Wade DT (2009) Writing SMART rehabilitation goals and achieving goal attainment scaling: a practical guide. Clinical Rehabilitation 23, 4, 352-61.

Cieza A, Brockow T, Ewert T, Amman E, Kollerits B, Chatterji S, Ustün TB, Stucki G (2002) Linking health-status measurements to the international classification of functioning, disability and health. Journal of Rehabilitation Medicine 34, 5, 205-210.

Cieza A, Geyh S, Chatterji S, Kostanjsek N, Ustün B, Stucki G (2005) ICF linking rules. An update based on lessons learned. Journal of Rehabilitation Medicine 37, 4, 212-218.

Creswell JW, Plano Clark VL (2018) Designing and conducting mixed methods research. 3. painos. Thousand Oaks, California: SAGE Publications, Inc.

Dekker J, de Groot V, ter Steeg AM, Vloothuis J, Holla J, Collette E, Satink T, Post L, Doodeman S, Littooij E (2020) Setting meaningful goals in rehabilitation: rationale and practical tool. Clinical Rehabilitation 34, 1, 3-12.

Hutting N, Oswald W, Staal JB, Engels JA, Nouwens E, Nijhuis van-der Sanden M, Heerken YF (2017) Physical therapists and importance of work participation in patients with musculoskeletal disorders: a focus group study. BMC Musculoskeletal Disorders 18, 196.

Hyvärinen M (2017) Kertomushaastattelu. Teoksessa M Hyvärinen, P Nikander, J Ruusuvuori (toim.) Tutkimushaastattelun käsikirja (verkkoaineisto 394 sivua). Vastapaino, Tampere.

Häkkinen A, Korniloff K, Aartolahti E, Tarnanen S, Nikander R, Heinonen A (2014) Näyttöön perustuva tuki- ja liikuntaelinsairauksien kuntoutus. Työpapereita 68. Kela, Helsinki.

Kamper SJ, Apledoorn AT, Chiarotto A, Smeets RJ, Ostelo RW, Guzman J, van Tulder MW (2014) Multidisciplinary biopsychosocial rehabilitation for chronic low back pain. Cochrane Database of Systematic Reviews 9:CD000963.

Karhula M, Heiskanen T, Seppänen-Järvelä R (2019) Kelan tuki- ja liikuntaelinsairauksien kuntoutus. Kuntoutujien ja kuntoutuksen palveluntuottajien kokemuksia. Sosiaali- ja terveysturvan raportteja 16. Kela, Helsinki.

Karhula M, Veijola A, Ylisassi H (2016) Julkaisussa I Autti-Rämö, A-L Salminen, M Rajavaara, A Ylinen (toim.) Kuntoutuminen. Duodecim, Helsinki.

Kayes NM, Mudge S, Bright FAS, McPherson K (2015) Whose behavior matters? Rethinking practioners behavior and its influence on rehabilitation outcomes. Teoksessa K McPherson, BE Gibson, A Leplege (toim.) Rethinking rehabilitation. Theory and practice. CRC Press, Taylor \& Francis Group, Boca Raton.

Kela (2016a) Palvelukuvaukset. Kelan avo- ja lai- 
tosmuotoisen kuntoutuksen standardi. Päivitetty 25.1.2016. Kela, Helsinki. Saatavissa: https://www.kela.fi/documents/10180/2272284/ $150624+$ päivitetty+Yleinen+osa.pdf/cbbcd0e1-fb35-42e7-a106-32bb9b8fc05e Viitattu 13.12.2019.

Kela (2016b) Kelan avo- ja laitosmuotoisen kuntoutuksen standardi. Tules-kurssi - Tuki- ja liikuntaelinsairaiden aikuisten kuntoutuskurssin palvelulinja. Kela, Helsinki. Saatavissa: https://www.kela.fi/documents/10180/2272284/ Tules-kurssi.pdf/f8e729d3-e3b6-4e39-813235e2b51b9558 Viitattu 13.12.2019.

Kela (2016c) Kelan avo- ja laitosmuotoisen kuntoutuksen standardi. Tules-avokurssi - Tukija liikuntaelinsairaiden aikuisten avomuotoisen kuntoutuskurssin palvelulinja. Kela, Helsinki. Saatavissa: https://www.kela.fi/ documents/10180/2272284/Tules-avokurssi.pdf/7ac3871a-cfd2-460e-898e-166d0f01e1d7 Viitattu 13.12.2019.

Kela (2017a) Kelan sairausvakuutustilasto 2016. Kela, Helsinki. Saatavissa: https://helda.helsinki. fi/handle/10138/224317. Viitattu 13.12.2019.

Kela (2017b) Kelan kuntoutustilasto 2017. Helsinki: Kela, SVT, 2018. Saatavissa: http://urn.fi/URN:NBN: fi-fe2018042318378. Viitattu 13.12.2019.

Kiresuk TJ, Sherman RE (1968) Goal attainment scaling: A general method for evaluating comprehensive community mental health programs. Community Mental Health Journal 4, 6, 443-53.

Krippendorff KH (2012) Content Analysis: An Introduction to Its Methodology, 3rd Ed. Thousand Oaks: SAGE Publications.

Kuntoutuksen uudistamiskomitea (2017) Kuntoutuksen uudistamiskomitean ehdotukset kuntoutusjärjestelmän uudistamiseksi. Sosiaali- ja terveysministeriön raportteja ja muistioita 41 . Sosiaali- ja terveysministeriö, Helsinki.

Laukkala T, Tuomi J, Sukula S (2015) GAS-menetelmä (Goal Attainment Scaling). Teoksessa S Sukula, K Vainiemi, T Laukkala (toim.) GAS. Menetelmästä sovellukseen. Kela, Helsinki.

Luomanen J, Nikander P (2017) Haavoittuvat haastateltavat. Teoksessa M Hyvärinen, P Nikander, J Ruusuvuori (toim.) Tutkimushaastattelun käsikirja(verkkoaineisto 394 sivua). Vastapaino, Tampere.

McPherson KM, Kayes NM, Kersten P (2015) MEANING as a smarter approach to goals in rehabilitation. Teoksessa RJ Siegert, WMM Levack (toim.) Rehabilitation goal setting. Theory, practice and evidence. CRC Press, Taylor \& Francis Group, Boca Raton.

Pietilä I (2017) Ryhmäkeskustelu. Teoksessa M Hyvärinen, P Nikander, J Ruusuvuori (toim.) Tutkimushaastattelun käsikirja (verkkoaineisto 394 sivua). Vastapaino, Tampere.

Reiterä T, Miettinen S, Rättö H, Vadén VM (2019) Kelan kuntoutuksen hyödyn arviointi 2017. Kuntoutusta kehittämässä. Kela, Helsinki, 49-53.

Reunanen M (2017) Toimijuus kuntoutuskokemusten kerronnassa ja fysioterapian kohtaamisissa. Acta Universitatis Lapponiensis 349. Saatavissa: http://urn.fi/URN:ISBN:978-952-484-997-5. Viitattu 13.12.2019. Lapin yliopisto, Rovaniemi.

Rose A, Rosewilliam S, Soundy A (2017) Shared decision making within goal setting in rehabilitati- on settings: A systematic review. Patient Education and Counseling 100, 1, 65-75.

Rose A, Soundy A, Rosewilliam S (2019) Shared decision-making within goal-setting in rehabilitation: a mixed-methods study. Clinical Rehabilitation 33, 3, 564-574.

Saito Y, Tomori K, Sawada T, Takahashi S, Nakatsuka S, Sugawara H, Yaginuma T, Sato T, Kumagai A, Nishimaki S, Hirano Y, Wauke Y, Weatherall M, Levack W (2019) Determining whether occupational therapy goals match between pairs of occupational therapists and their clients: a cross-sectional study, Disability and Rehabilitation DOI: 10.1080/09638288.2019.1643417

Sallinen M, Bärlund E, Koivuniemi M, Heinonen T (2015) Kohti yhteisiä tavoitteita. GAS-koulutuksen arviointihankkeen loppuraportti. Työpapereita 79. Kela, Helsinki, 36-39.

Scobbie L, Dixon D, Wyke S (2011) Goal setting and action planning in the rehabilitation setting: Development of a theoretically informed practice framework. Clinical Rehabilitation 25, 468-482.

Seppänen-Järvelä R (2017) Monimuotoinen implementaatiotutkimus. Sosiaalilääketieteellinen Aikakauslehti 54, 2, 151-154.

Seppänen-Järvelä R, Åkerblad A, Haapakoski K (2019) Monimenetelmällisen tutkimuksen integroivat strategiat. Yhteiskuntapolitiikka 84, 3, 332-339.

Siegert RJ, Levack WMM (2015) (toim.) Rehabilitation goal setting. Theory, practice and evidence. CRC Press, Boca Raton.

Sipari S, Vänskä N, Lehtonen K, Pihlava J (2019) GAS-menetelmän käyttö Kelan sopeutumisvalmennuskursseilla. Kuntoutujan omat tavoitteet -tutkimus. Sosiaali- ja terveysturvan raportteja 20. Kela, Helsinki.

Sormunen M, Saaranen T, Tossavainen K, Turunen H (2013) Monimenetelmätutkimus terveystieteissä. Sosiaalilääketieteellinen aikakauslehti 50, 4, 312-321.

Stevens A, Beurskens A, Köke A, van der Weijden T (2013) The use of patient-specific measurement instruments in the process of goal-setting. A systematic review of available instruments and their feasibility. Clinical Rehabilitation 27, 11, 1005-1019.

Sukula S, Vainiemi K, Laukkala T (2015) GAS-käsikirja. Helsinki: Kela. Saatavissa: <www.kela.fi/ gas-menetelma>. Viitattu 13.12.2019.

Veijola A, Honkanen H, Lappalainen P (2015) Asiakkaan osallisuuden mahdollistava ja sitä tukeva haastattelukeskustelu. Teoksessa S Sukula, K Vainiemi, T Laukkala (toim.) GAS. Menetelmästä sovellukseen. Kela, Helsinki.

Wensing M (2015) Implementation science in healthcare: Introduction and perspective. Zeitschrift für Evidenz, Fortbildung und Qualität im Gesundheitswesen 109, 2, 97-102.

Zhang Y, Chiu C (2011) Goal commitment and alignment of personal goals predict group identification only when the goals are shared. Group Processes \& Intergroup Relations 15, 3, 425-437.

Ylisassi H, Sormunen E, Mäenpää-Moilanen E, Martimo KP (2018) Tavoitteet kuntoutujan toimijuuden edistäjinä tules-kurssilla. Kuntoutus 41, 3, 5-20. 